\title{
Communication
}

\section{Oxidation of dibenzothiophene using oxygen and a vanadophosphate catalyst for ultra-deep desulfurization of diesels}

\author{
Nanfang Tang a,b, Xiaoping Zhao c, Zongxuan Jiang a,*, Can Li a,\# \\ a State Key Laboratory of Catalysis, Dalian Institute of Chemical Physics, Chinese Academy of Sciences, Dalian 116023, Liaoning, China \\ b University of Chinese Academy of Sciences, Beijing 100049, China \\ 'Shaanxi Yanchang Petroleum (Group) Co., Ltd., Xi'an 710075, Shaanxi, China
}

\section{A R T I C L E I N F O}

Article history:

Received 30 May 2014

Accepted 18 July 2014

Published 20 September 2014

Keywords:

Oxidative desulfurization

Molecular oxygen

Vanadophosphate

Dibenzothiophene

\section{A B S T R A C T}

A bicapped Keggin structure vanadophosphate showed high catalytic activity in the oxidation of dibenzothiophene (DBT) to sulfone using molecular oxygen as oxidant under mild reaction conditions. This is a promising approach to the ultra-deep desulfurization of fuels (e.g. diesel) as sulfones can be removed from the fuel by extraction or selective adsorption.

(c) 2014, Dalian Institute of Chemical Physics, Chinese Academy of Sciences. Published by Elsevier B.V. All rights reserved.
Sulfur-containing compounds are undesirable in fuels because they contribute to acid rain and cause deactivation of catalysts in automotive applications. The Environmental Protection Agency regulations and EU Euro $\mathrm{V}$ standards require the $S$ level in diesel fuels to be less than 15 and 10 ppm, respectively. The current technology is conventional hydrodesulfurization (HDS), which shows high efficiency for the removal of thiols, sulfides, and disulfides. However, it is difficult to reduce refractory sulfur-containing compounds such as dibenzothiophene (DBT) and its derivatives, especially 4,6-dimethyldibenzothiophene (4,6-DMDBT), to an ultra-low level using only conventional HDS. This process requires severe operating conditions such as high temperatures, high pressures, and high hydrogen consumption to achieve the ultra-deep desulfurization of diesel. From an economic and environmental point of view, it is necessary to develop an alternative ultra-deep desulfurization processes $[1,2]$. One promising strategy to re- move sulfur-containing compounds from fuel oils (e.g. diesel) is oxidative desulfurization (ODS). ODS avoids the use of hydrogen and allows the process to be conducted under ambient conditions. Moreover, refractory compounds, mainly 4,6-DMDBT, can be removed efficiently, which are difficult to remove with conventional HDS [3].

$\mathrm{H}_{2} \mathrm{O}_{2}$ is the highly reactive oxidant mostly used for ODS. It has been used with catalysts like Ti molecular sieves [4], vanadium oxide [5], $\mathrm{WO}_{x} / \mathrm{ZrO}_{2}$ [6], polyoxometallates [7,8], and amphiphilic catalysts in emulsions $[9,10]$. Other oxidants like organic and inorganic peroxyacids, $\mathrm{NO}_{2}$, tert-butyl-hydroperoxide, and $\mathrm{O}_{3}$ have also been reported for ODS [11-13]. Taking into account environmental and economic concerns, the utilization of $\mathrm{O}_{2}$ as the oxidant for ODS is most desirable [14,15]. In this communication, we report a highly efficient oxidation of refractory compounds DBT using molecular oxygen catalyzed by tetradecavanadophosphate $\left[\mathrm{C}_{8} \mathrm{H}_{17} \mathrm{~N}\left(\mathrm{CH}_{3}\right)_{3}\right]_{5} \mathrm{H}_{4} \mathrm{PV}_{14} \mathrm{O}_{42}$

\footnotetext{
* Corresponding author. Tel: +86-411-84379990; Fax: +86-411-84694447; E-mail: zxjiang@dicp.ac.cn

\# Corresponding author. Tel: +86-411-84379070; Fax: +86-411-84694447; E-mail: canli@dicp.ac.cn

This work was supported by the National Natural Science Foundation of China (21173214).

DOI: 10.1016/S1872-2067(14)60194-7 | http://www.sciencedirect.com/science/journal/18722067 | Chin. J. Catal., Vol. 35, No. 9, September 2014
} 

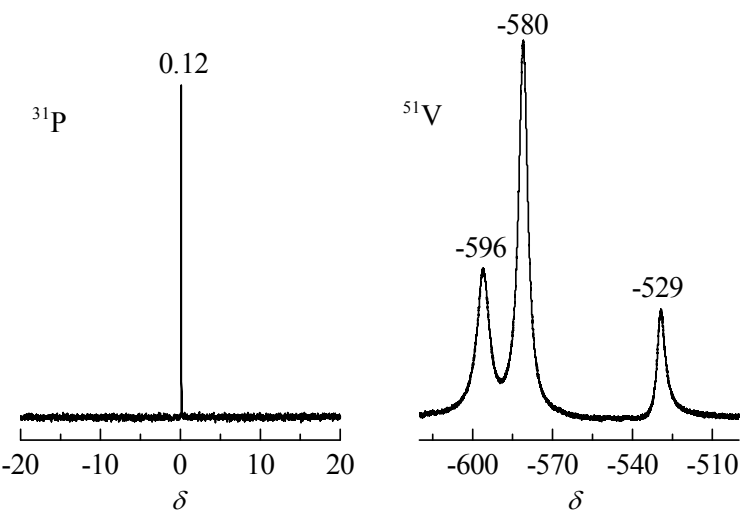

Fig. 1. ${ }^{31} \mathrm{P}$ and ${ }^{51} \mathrm{~V}$ NMR spectra of tetradecavanadophosphate.

$\left(\mathrm{Q}_{5} \mathrm{H}_{4} \mathrm{PV}_{14} \mathrm{O}_{42}\right)$ under mild conditions.

$\mathrm{Q}_{5} \mathrm{H}_{4} \mathrm{PV}_{14} \mathrm{O}_{42}$ was isolated by treating a mixture of metavanadate and orthophosphate $(\mathrm{V}: \mathrm{P}=4: 1, \mathrm{pH}=2.3)$ with $\mathrm{C}_{8} \mathrm{H}_{17} \mathrm{~N}\left(\mathrm{CH}_{3}\right)_{3} \mathrm{Cl}$. The Fouriter transform infrared (FT-IR) spectrum of $\mathrm{Q}_{5} \mathrm{H}_{4} \mathrm{PV}_{14} \mathrm{O}_{42}$ showed four intense bands from 700 to $1100 \mathrm{~cm}^{-1}$, which served as the signature of the Keggin anion. The band at $1060 \mathrm{~cm}^{-1}$ was assigned to the stretching of the $\mathrm{P}-\mathrm{O}$ bond of the central $\mathrm{PO}_{4}$. According to studies by Rocchiccioli-Deltcheff et al. $[16,17]$, the vibrational motion of the phosphate group is independent of the remaining "cage" of the Keggin anion. The bond at $946 \mathrm{~cm}^{-1}$ was assigned to the stretching of the terminal $\mathrm{V}-\mathrm{O}_{\mathrm{t}}$ bond. The two bands at 866 and $804 \mathrm{~cm}^{-1}$ were the asymmetrical $\mathrm{V}-\mathrm{O}_{\mathrm{b}}-\mathrm{V}$ stretching vibrations. Figure 1 shows the ${ }^{31} \mathrm{P}$ and $51 \mathrm{~V}$ NMR spectra of tetradecavanadophosphate, which were well explained by the "bicapped Keggin" structure of the anion. The ${ }^{31} \mathrm{P}$ NMR spectrum showed a single peak at $0.12 \mathrm{ppm}$. The $51 \mathrm{~V}$ NMR spectrum showed three broad peaks with the relative intensity ratio of $2: 8: 4$. The peak at -529 ppm was assigned to the "capping" 5-coordinated vanadium. The two peaks at -580 and $-596 \mathrm{ppm}$ were assigned to the 6-coordinated vanadium in the Keggin unit $[18,19]$.

The oxidation of the DBT-containing model oil was conducted in a flask at $90{ }^{\circ} \mathrm{C}$ with $\mathrm{O}_{2}$ gas bubbled in. Samples were periodically taken by a pipette and quantified using an external

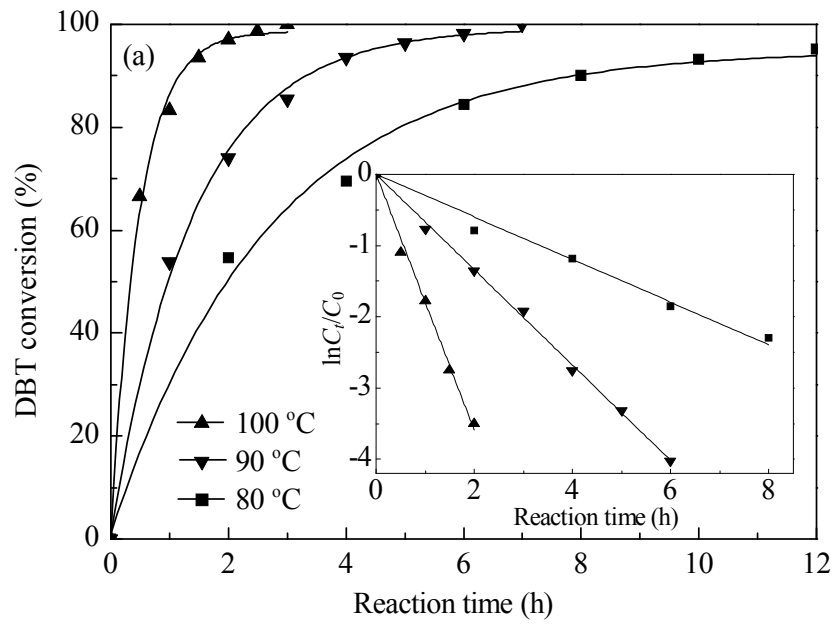

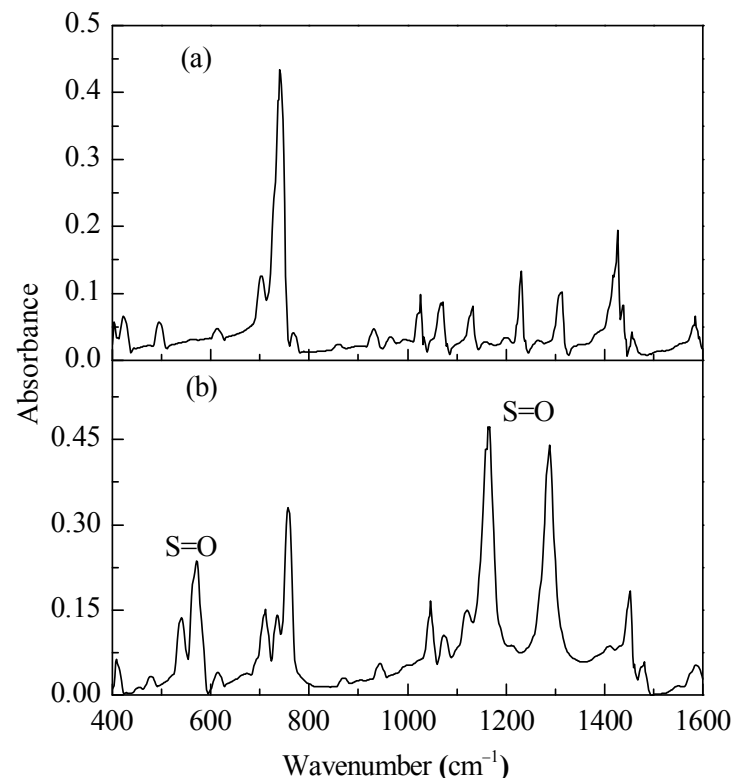

Fig. 2. FT-IR spectra of DBT before (a) and after (b) reaction.

calibration curve. The sulfur-containing compounds present in the diesel were analyzed by a gas chromatograph coupled to a flame photometric detector (GC-FPD). A white needle-shaped crystal was obtained when the reaction system was cooled down to room temperature. The product was determined to be crystallized dibenzothiophene sulfone $\left(\mathrm{DBTO}_{2}\right)$ by FT-IR (Fig. 2) and ${ }^{1} \mathrm{H}$ NMR ( $\left.\delta 8.20(2 \mathrm{H}), 7.98(2 \mathrm{H}), 7.80(2 \mathrm{H}), 7.65(2 \mathrm{H})\right)$. The band at $1293 \mathrm{~cm}^{-1}$ corresponded to the asymmetrical stretching vibration of $\mathrm{S}=0$ while the symmetrical stretch was at $1165 \mathrm{~cm}^{-1}$. The bands at 571 and $540 \mathrm{~cm}^{-1}$ were assigned to the bending vibration of $\mathrm{S}=0$. The mass spectrum of product showed the molecular ion peak at $216(\mathrm{~m} / \mathrm{z})$, which agreed with the molecular weight of $\mathrm{DBTO}_{2}$ [20].

Figure 3(a) shows the DBT conversion and $\ln \left(C_{t} / C_{0}\right)$ vs. reaction time, which revealed the catalytic reaction kinetics. $C_{t} / C_{0}$ was defined as the ratio of the concentration of final and initial sulfur-containing compounds. Increasing reaction temperature from 80 to $100{ }^{\circ} \mathrm{C}$ led to a remarkable enhancement of the

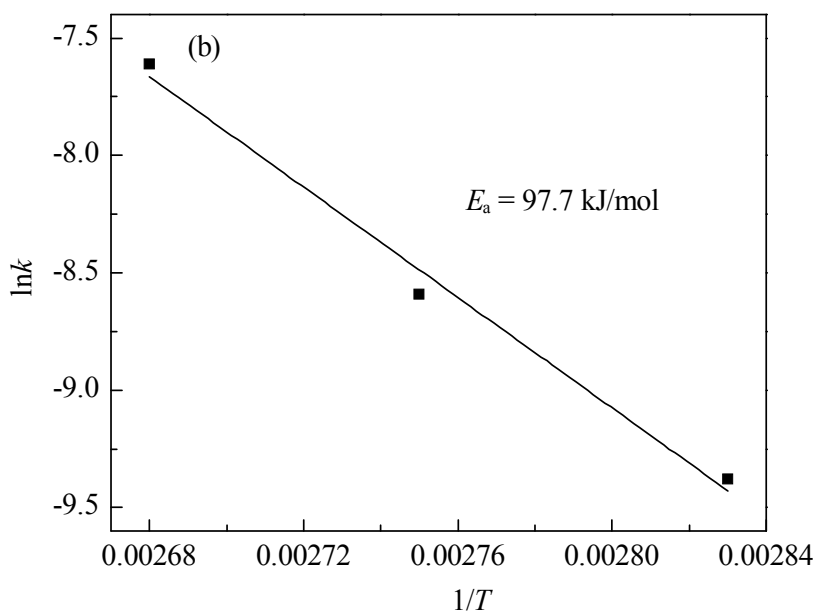

Fig. 3. (a) Conversion of DBT and $\ln C_{t} / C_{0}$ vs. reaction time at different temperatures; (b) Apparent activation energy for the ODS of DBT. Reaction conditions: $\mathrm{Q}_{5} \mathrm{H}_{4} \mathrm{PV}_{14} \mathrm{O}_{42} 40 \mathrm{mg}$, DBT (S: $500 \mathrm{ppm}$ ) in $20 \mathrm{ml}$ decalin, oxidant $\mathrm{O}_{2} 1 \mathrm{~atm}$. 


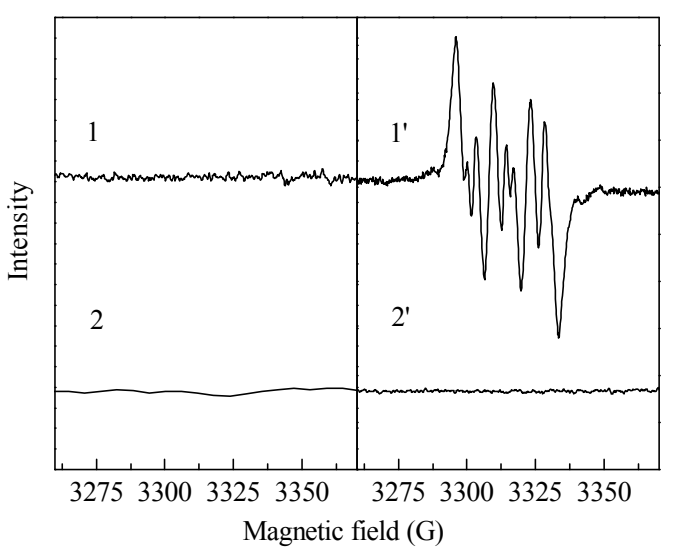

Fig. 4. In situ ESR spectra obtained in the oxidative desulfurization process. (1) Sample tested without catalyst at $60^{\circ} \mathrm{C}$; (2) Sample tested without catalyst at $25^{\circ} \mathrm{C}$; (1') Sample tested with catalyst at $60^{\circ} \mathrm{C}$; $\left(2^{\prime}\right)$ Sample tested with catalyst at $25^{\circ} \mathrm{C}$.

conversion of DBT. At $100{ }^{\circ} \mathrm{C}$, the conversion of DBT was $100 \%$ in $3 \mathrm{~h}$. The linear fit of $\ln \left(C_{t} / C_{0}\right)$ against reaction time demonstrated pseudo-first order kinetics for the oxidation of DBT on $\mathrm{Q}_{5} \mathrm{H}_{4} \mathrm{PV}_{14} \mathrm{O}_{42}$. The apparent activation energy for the ODS of DBT on $\mathrm{Q}_{5} \mathrm{H}_{4} \mathrm{PV}_{14} \mathrm{O}_{42}$ was $97.7 \mathrm{~kJ} / \mathrm{mol}$ (Fig. 3(b)). At $100{ }^{\circ} \mathrm{C}$, the conversion of 4,6-DMDBT was $100 \%$ in $4 \mathrm{~h}$.

To study the mechanism of the activation of sulfur-containing compounds, an ESR spin-trap technique with DMPO as a trap for $\mathrm{O}_{2} \cdot-$ was employed. Figure 4 shows the ESR signals obtained from the in situ ODS process. No ESR signals were observed at 25 and $60{ }^{\circ} \mathrm{C}$ for the reaction system without $\mathrm{Q}_{5} \mathrm{H}_{4} \mathrm{PV}_{14} \mathrm{O}_{42}$. With the introduction of $\mathrm{Q}_{5} \mathrm{H}_{4} \mathrm{PV}_{14} \mathrm{O}_{42}$, no ESR signal was observed at $25{ }^{\circ} \mathrm{C}$. When the reaction system was heated to $60{ }^{\circ} \mathrm{C}$, a broad, 8-line ESR signal appeared. The ESR signal was centered at $g=2.0088$, and can be assigned to oxygen species [21]. The 8-line ESR signal was attributable to the superposition of $\mathrm{O}_{2}$-- and $0^{--}$[22]. These results indicated that active oxygen species were produced through the reaction of $\mathrm{Q}_{5} \mathrm{H}_{4} \mathrm{PV}_{14} \mathrm{O}_{42}$ with $\mathrm{O}_{2}$. Therefore, we proposed a mechanism where first, $\mathrm{O}_{2}$ was activated to form an active species when $\mathrm{O}_{2}$ coordinated to $\mathrm{Q}_{5} \mathrm{H}_{4} \mathrm{PV}_{14} \mathrm{O}_{42}$; then, the active species oxidized DBT to $\mathrm{DBTO}_{2}$.
In conclusion, we synthesized a "bicapped Keggin" structure vanadophosphate which showed high catalytic activity in the oxidation of DBT to sulfone using oxygen. This provides a new pathway for the ODS of diesel with oxygen as oxidant.

\section{References}

[1] Song C S. Catal Today, 2003, 86: 211

[2] Chandra Srivastava V. RSC Adv, 2012, 2: 759

[3] Jiang Z X, Lü H Y, Zhang Y N, Li C. Chin J Catal (蒋宗轩, 吕宏缨, 张 永娜, 李灿. 催化学报), 2011, 32: 707

[4] Chica A, Corma A, Domine M E. J Catal, 2006, 242: 299

[5] Caero L C, Hernandez E, Pedraza F, Murrieta F. Catal Today, 2005, 107: 564

[6] Ramirez-Verduzco L F, Torres-Garcia E, Gómez-Quintana R, Gonzalez-Penã V, Murrieta-Guevara F. Catal Today, 2004, 98: 289

[7] Yazu K, Yamamoto Y, Furuya T, Miki K, Ukegawa K. Energy Fuels, 2001, 15: 1535

[8] Zhang B Y, Jiang Z X, Li J, Zhang Y N, Lin F, Liu Y, Li C.J Catal, 2012, 287: 5

[9] Li C, Jiang Z X, Gao J B, Yang Y X, Wang S J, Tian F P, Sun F X, Sun X P, Ying P L, Han C R. Chem-Eur J, 2004, 10: 2277

[10] Zhang Y N, Wang L, Zhang Y L, Jiang Z X, Li C. Chin J Catal (张永娜, 王璐, 张玉良, 蒋宗轩, 李灿. 催化学报), 2011, 32: 235

[11] Tam P S, Kittrell J R, Eldridge J W. Ind Eng Chem Res, 1990, 29: 321

[12] Yang L W, Li J, Yuan X D, Shen J, Qi Y T. J Mol Catal A, 2007, 262: 114

[13] Babich I V, Moulijn J A. Fuel, 2003, 82: 607

[14] Tang N F, Zhang Y N, Lin F, Lü H Y, Jiang Z X, Li C. Chem Commun, 2012, 48: 11647

[15] Lü H Y, Zhang Y N, Jiang Z X, Li C. Green Chem, 2010, 12: 1954

[16] Rocchiccioli-Deltcheff C, Fournier M, Franck R, Thouvenot R. Inorg Chem, 1983, 22: 207

[17] Edwards J C, Thiel C Y, Benac B, Knifton J F. Catal Lett, 1998, 51: 77

[18] Selling A, Andersson I, Pettersson L, Schramm C M, Downey S L, Grate J H. Inorg Chem, 1994, 33: 3141

[19] Kato R, Kobayashi A, Sasaki Y. Inorg Chem, 1982, 21: 240

[20] Ogunlaja A S, Chidawanyika W, Antunes E, Fernandes M A, Nyokong T, Torto N, Tshentu Z R. Dalton Trans, 2012, 41: 13908

[21] Leonard S, Gannett P M, Rojanasakul Y, Schwegler-Berry D, Castranova V, Vallyathan V, Shi X L. J Inorg Biochem, 1998, 70: 239

[22] Lin F, Wang D G, Jiang Z X, Ma Y, Li J, Li R G, Li C. Energy Environ Sci, 2012, 5: 6400

\section{Graphical Abstract}

Chin. J. Catal., 2014, 35: 1433-1437 doi: 10.1016/S1872-2067(14)60194-7

Oxidation of dibenzothiophene using oxygen and a vanadophosphate catalyst for ultra-deep desulfurization of diesels

Nanfang Tang, Xiaoping Zhao, Zongxuan Jiang*, Can Li*

Dalian Institute of Chemical Physics, Chinese Academy of Sciences;

University of Chinese Academy of Sciences;

Shaanxi Yanchang Petroleum (Group) Co., Ltd.

Oxygen was by interaction with a vanadophosphate, and it oxidized dibenzothiophene to sulfone.
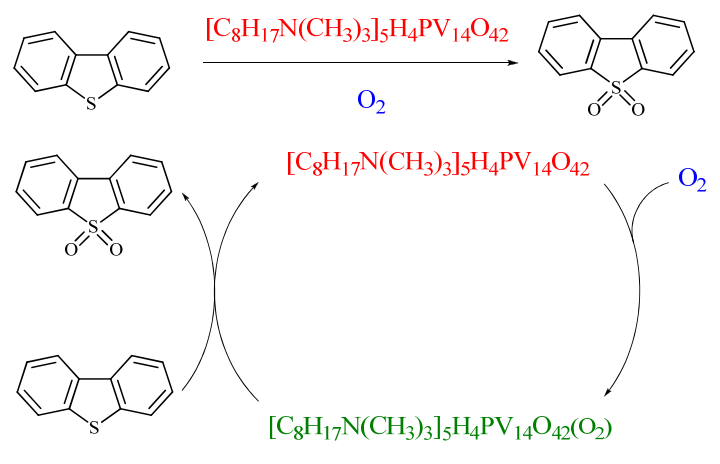


\title{
分子氧为氧化剂磷钒酸盐为催化剂超深度氧化脱除柴油中的二苯并噻吩
}

\author{
唐南方 ${ }^{\mathrm{a}, \mathrm{b}}$, 赵小平 ${ }^{\mathrm{c}}$, 蒋宗轩 ${ }^{\mathrm{a},{ }^{*}}$, 李 灿 $^{\mathrm{a}, \#}$ \\ $\mathrm{a}$ 中国科学院大连化学物理研究所, 催化基础国家重点实验室, 辽宁大连 116023 \\ $\mathrm{b}$ 中国科学院大学, 北京 100049 \\ c 陕西延长石油(集团)有限责任公司, 陕西西安 710075
}

\begin{abstract}
摘要: 一种“双帽Keggin型”磷锄盐在温和的反应条件下以分子氧为氧化剂氧化二苯并噻吩至二苯并噻吩砜的反应中表现出很 高的催化活性. 用溶剂萃取或者选择吸附等方法可轻易地将反应产生的二苯并噻吩砜从油品中除去. 这提供了一种新型的分子 氧为氧化剂的超深度氧化脱硫方法.
\end{abstract}

关键词: 氧化脱硫; 分子氧; 磷钒酸盐; 二苯并噻吩

收稿日期: 2014-05-30. 接受日期: 2014-07-18. 出版日期: 2014-09-20.

*通讯联系人. 电话: (0411)84379990; 传真: (0411)84694447; 电子信箱: zxjiang@dicp.ac.cn

\#通讯联系人. 电话: (0411)84379070; 传真: (0411)84694447; 电子信息: canli@dicp.ac.cn

基金来源：国家自然科学基金(21173214).

本文的英文电子版由Elsevier出版社在ScienceDirect上出版(http://www.sciencedirect.com/science/journal/18722067).

燃料油中含硫化合物可导致酸雨和发动机尾气三 效催化剂失活, 是急需除去的物质. 美国环境保护局和 欧洲欧 $\mathrm{V}$ 标准分别要求燃油中的硫含量低于 15 和 10 ppm. 目前, 广泛使用的传统的加氢脱硫技术(HDS)能够 高效地脱除燃油中的硫醇、硫醚和二硫醚等硫化物. 但 很难将二苯并噻吩(DBT)及其衍生物4,6-二甲基二苯并 噻吩(4,6-DMDBT)脱除以达到超低硫标准. HDS操作条 件苛刻, 需要高温、高压和高氢耗来达到超深度脱硫的 目标. 从经济和环保的角度去考虑, 急需开发新型的超 深度脱硫技术 ${ }^{[1,2]}$. 氧化脱硫(ODS) 是一种很有前景的超 深度脱硫技术, 它不使用昂贵的氢源, 操作条件温和, 能 够高效地氧化脱除加氢脱硫难以脱除的含硫化合物 ${ }^{[3]}$.

$\mathrm{H}_{2} \mathrm{O}_{2}$ 具有较高的反应活性, 是一种常用的ODS氧化 剂, 可用于多种催化剂体系, 如 Ti分子篮体系 ${ }^{[4]}$ 、钒氧化 物体系 ${ }^{[5]} 、 \mathrm{WO}_{x} / \mathrm{ZrO}_{2}$ 体系 ${ }^{[6]}$ 、杂多酸盐体系 ${ }^{[7,8]}$ 和乳液催 化剂体系 ${ }^{[9,10]}$. 文献中报道的氧化脱硫体系也使用其他 的氧化剂如, 有机和无机过氧酸、 $\mathrm{NO}_{2}$ 、叔丁基过氧化氢 和臭氧 ${ }^{[11-13]}$. 从环保和经济性去考虑, 分子氧是最理想 的ODS氧化剂 ${ }^{[14,15]}$. 本文报道了一种在温和反应条件 下，采用分子氧做氧化剂，磷钒十四酸盐 $\left[\mathrm{C}_{8} \mathrm{H}_{17} \mathrm{~N}\left(\mathrm{CH}_{3}\right)_{3}\right]_{5} \mathrm{H}_{4} \mathrm{PV}_{14} \mathrm{O}_{42}\left(\mathrm{Q}_{5} \mathrm{H}_{4} \mathrm{PV}_{14} \mathrm{O}_{42}\right)$ 为催化剂高效 地催化氧化加氢脱硫难以脱除的含硫化合物(DBT)的体 系.

将偏钒酸钠和磷酸的混合溶液 $(\mathrm{V}: \mathrm{P}=4: 1, \mathrm{pH}=2.3)$ 和 $\mathrm{C}_{8} \mathrm{H}_{17} \mathrm{~N}\left(\mathrm{CH}_{3}\right)_{3} \mathrm{Cl}$ 混合制得磷钒十四酸盐 $\mathrm{Q}_{5} \mathrm{H}_{4} \mathrm{PV}_{14} \mathrm{O}_{42}$. 磷钒十四酸盐 $\mathrm{Q}_{5} \mathrm{H}_{4} \mathrm{PV}_{14} \mathrm{O}_{42}$ 的红外光谱 (FT-IR) 谱中, 700-1100 $\mathrm{cm}^{-1}$ 之间的四个强吸收峰是Keggin型阴离子 的特征吸收峰; $1060 \mathrm{~cm}^{-1}$ 处的吸收峰可归属为中心 $\mathrm{PO}_{4}$
的P-O振动. Rocchiccioli-Deltcheff等 ${ }^{[16,17]}$ 研究发现磷酸 基团的振动独立于Keggin阴离子. $946 \mathrm{~cm}^{-1}$ 处的吸收峰 可归属为端位 $\mathrm{V}-\mathrm{O}_{\mathrm{t}}$ 振动. 866 和 $804 \mathrm{~cm}^{-1}$ 两处的吸收峰 可归属为 $\mathrm{V}-\mathrm{O}_{\mathrm{b}}-\mathrm{V}$ 的不对称振动. ${ }^{31} \mathrm{P}$ 和 ${ }^{51} \mathrm{~V}$ 的 $\mathrm{NMR}$ 谱图 很好地解释了磷钒十四酸盐阴离子的双帽Keggin型结 构(图1). ${ }^{31} \mathrm{P}$ NMR谱有一个位于 $0.12 \mathrm{ppm}$ 处的单峰. ${ }^{51} \mathrm{~V}$ NMR谱呈现出三个相对强度为 $2: 8: 4$ 的宽峰; $-529 \mathrm{ppm}$ 处的峰可归属为“帽位”5配位的钒原子; -580 和 -596 $\mathrm{ppm}$ 的峰可归属为Keggin单元中 6 配位的钒原子 ${ }^{[18,19]}$.

模型油DBT的氧化在 $90{ }^{\circ} \mathrm{C}$, 鼓入氧气的三口烧瓶 中进行的. 每隔一定时间用吸管取样, 用外标曲线法测 定油品中的硫含量. 采用GC-FPD分析检测含硫化合物. 当反应体系冷却至室温, 有白色针状晶体析出. 通过IR (图2)和 ${ }^{1} \mathrm{H} \operatorname{NMR}(\delta 8.20(2 \mathrm{H}), 7.98(2 \mathrm{H}), 7.80(2 \mathrm{H}), 7.65$ $(2 \mathrm{H}))$ 表征得出该产物为二苯并噻吩砜 $\left(\mathrm{DBTO}_{2}\right) .129$ 和 $1165 \mathrm{~cm}^{-1}$ 处吸收峰可分别归属为 $\mathrm{S}=\mathrm{O}$ 的不对称伸缩振 动和 $\mathrm{S}=\mathrm{O}$ 的对称伸缩振动. 571 和 $540 \mathrm{~cm}^{-1}$ 处吸收峰可归 属为 $\mathrm{S}=\mathrm{O}$ 的弯曲振动. $\mathrm{GC}-\mathrm{MS}$ 结果也表明 $216(\mathrm{~m} / \mathrm{z})$ 分子 离子峰在处为 $\mathrm{DBTO}_{2}$, 与文献结果一致 ${ }^{[20]}$.

图3(a) 给出了DBT转化率和 $\ln \left(C_{t} / C_{0}\right)$ 对反应时间的 关系可以看出, 该反应为准一级反应. 当温度从 $80{ }^{\circ} \mathrm{C}$ 上 升至 $100{ }^{\circ} \mathrm{C}$ 时, DBT的转化速率大幅提高; $100{ }^{\circ} \mathrm{C}$ 反应 3 $\mathrm{h}, \mathrm{DBT}$ 完全被氧化成DBTO $\mathrm{D}_{2}$. 该反应的表观活化能为 $97.7 \mathrm{~kJ} / \mathrm{mol}$ (图3(b)). $100{ }^{\circ} \mathrm{C}$ 反应 $4 \mathrm{~h}, 4,6-\mathrm{DMDBT}$ 完全被 氧化成 $\mathrm{DBTO}_{2}$.

我们使用原位ESR自旋-捕获技术, 用DMPO作为氧 自由基捕获剂来考察反应体系硫化物氧化的机理. 图4 给出了在催化剂 $\mathrm{Q}_{5} \mathrm{H}_{4} \mathrm{PV}_{14} \mathrm{O}_{42}$ 存在下, 原位分子氧氧化 
DBT的特征ESR谱图. 可以看出, 在不加催化剂, 无论是 室温还是加热都没有活性氧物种的信号; 当加入催化剂 后, 在室温也未出现活性氧物种; 当加热到 $60^{\circ} \mathrm{C}$ 时, 有 一八重锋的出现, 峰信号集中在中心场 $g=2.008$, 这归属 为活性氧物种信号 ${ }^{[21]}$. 该八重峰可认为是超氧自由基 $\mathrm{O}_{2}{ }^{-}$和 $\mathrm{O}^{-}$信号叠加而成 ${ }^{[22]}$. 这表明催化剂 $\mathrm{Q}_{5} \mathrm{H}_{4} \mathrm{PV}_{14} \mathrm{O}_{42}$ 和 $\mathrm{O}_{2}$ 相互作用可产生活性氧物种. 由此, 我们推测出该
过程可能的反应机理: 首先, $\mathrm{O}_{2}$ 和催化剂 $\mathrm{Q}_{5} \mathrm{H}_{4} \mathrm{PV}_{14} \mathrm{O}_{42}$ 相 互作用产生活性氧物种; 然后, 该活性氧物种将 $\mathrm{DBT}$ 氧 化成 $\mathrm{DBTO}_{2}$.

综上, 我们合成了一种“双帽Keggin型”磷钒酸盐. 该磷钒酸盐在以分子氧为氧化剂氧化 $\mathrm{DBT}$ 至 $\mathrm{DBTO}_{2}$ 的 反应中表现出很高的催化活性. 这为以分子氧为氧化剂 氧化脱除柴油中含硫化合物提供了一种新的方法.

\section{Impact Factor of Chinese Journal of Catalysis is $\mathbf{1 . 5 5 2}$}

According to the 2013 Journal Citation Reports (JCR) published by Thomson Reuters, the impact factor of Chinese Journal of Catalysis reached 1.552. This has been the highest SCI impact factor of Chinese Journal of Catalysis since she was included in the Science Citation Index-Expanded (SCI-E) in 2001, indicating that the Journal is now read and referred by more and more readers in the world.

(Editorial Office of Chinese Journal of Catalysis, 2014-08-20)

\section{《催化学报》2013 年 SCI 影响因子为 1.552}

根据美国汤森路透 (Thomson Reuters) 2013 年 7 月 30 日公布的 2013 年度《期刊引证报告》 (Journal Citation Reports, JCR), 《催化学报》 2013 年 SCI 影响因子达到 1.552, 总被引频次为 2073,5 年影响因子为 1.180 . 其中, 影响因子 均位居 SCI 收录的中文化学类期刊的第 1 名, 也是历年来我国中文化学类期刊 SCI 影响因子的最高值. 这表明, 《催化 学报》正在被越来越多的国内外同行阅读和参考, 该刊在国际学术交流中的作用进一步提高. 《催化学报》取得的成 绩离不开广大作者、审稿专家和读者多年来的大力支持和帮助, 在此向您表示衷心感谢! 